\title{
PLPP3 wt Allele
}

National Cancer Institute

\section{Source}

National Cancer Institute. PLPP3 wt Allele. NCI Thesaurus. Code C105942.

Human PLPP3 wild-type allele is located in the vicinity of 1 p32.2 and is approximately 151 $\mathrm{kb}$ in length. This allele, which encodes phospholipid phosphatase 3 protein, plays a role in both diacylglycerol metabolism and phospholipase D cell signaling. 